\title{
ANALISIS KELAYAKAN FINANSIAL USAHATANI JAMBU BIJI KRISTAL (Psidium guajava L.) \\ (Studi Kasus : Petani Jambu Biji Kristal di Desa Warisa Kecamatan Talawaan Kabupaten Minahasa Utara)
}

\author{
Sunarti Poppie S. Datundugon \\ Femi Hadidjah Elly \\ Jolanda Kitsia Juliana Kalangi
}

\begin{tabular}{ll}
\hline Naskah diterima melalui Email agrisosioekonomi@unsrat.ac.id & : Selasa, 3 November 2020 \\
Disetujui diterbitkan & : Kamis, 5 November 2020 \\
\hline
\end{tabular}

\begin{abstract}
This study aims to determine the potential and opportunities for developing crystal guava farming and to analyze the financial feasibility of crystal guava farming in Warisa Village, Talawaan Sub-district, North Minahasa Regency. The study was conducted from July to October 2020. The selection of respondents was carried out by purposive sampling method. The research used primary data and secondary data. Primary data obtained from interviews, based on a questionnaire to one guava crystal farmer. Secondary data were obtained from the Head of Village Office, the Central Statistics Agency (BPS) and the Agriculture Office of North Minahasa Regency. The results showed that the potential of natural resources, namely the availability of land for the development of crystal guava cultivation is still quite extensive and the use of existing land can still be maximized. Warisa Village fulfills the growing requirements for the development of guava plants because it is located at an altitude of \pm 1-500 meters above sea level (masl), has a temperature of around 26.9-33,710 C in the daytime, rainfall is 1,993 mm year, type of soil is loose and fertile. Based on the financial feasibility analysis, Warisa Village's guava crystal cultivation is financially feasible to continue because it meets all investment criteria. ${ }^{* e p r m *}$
\end{abstract}

Keywords: Crystal guava; farming; potential; financial feasibility

ABSTRAK

Penelitian ini bertujuan untuk mengetahui bagaimana potensi dan peluang pengembangan usahatani jambu biji kristal dan untuk menganalisis kelayakan finansial usahatani jambu biji kristal di Desa Warisa Kecamatan Talawaan Kabupaten Minahasa Utara. Penelitian dilaksanakan pada bulan Juli sampai Oktober 2020. Pemilihan responden dilakukan secara purposive sampling. Data yang digunakan adalah data primer dan data sekunder. Data primer diperoleh dari hasil wawancara, berdasarkan kuesioner kepada petani jambu biji kristal berjumlah satu orang. Data sekunder diperoleh dari Kantor Hukum Tua, Badan Pusat Statisitik (BPS) dan Dinas Pertanian Kabupaten Minahasa Utara. Hasil penelitian menunjukkan bahwa potensi sumberdaya alam yaitu ketersediaan lahan untuk pengembangan budidaya tanaman jambu kristal masih cukup luas dan pemanfaatan lahan yang ada masih dapat dimaksimalkan. Desa Warisa memenuhi persyaratan tumbuh untuk pengembangan tanaman jambu kristal karena terletak pada ketinggian $\pm 1-500$ meter diatas permukaan laut (mdpl), memiliki suhu sekitar 26,9-33,710C disiang hari, curah hujan 1,993 mm/tahun, jenis tanah gembur dan subur Berdasarkan analisa kelayakan finansial maka usahatani jambu kristal Desa Warisa secara finansial layak untuk dilanjutkan karena memenuhi semua kriteria investasi. *eprm*

Kata kunci : Jambu kristal, potensi, kelayakan finansial, usaha tani 


\section{PENDAHULUAN}

\section{Latar Belakang}

Produksi buah jambu biji mengalami peningkatan mulai terjadi dari tahun 2015 hingga 2019. Secara nasional produksi jambu biji mengalami peningkatan produksi mulai tahun 2015 sebesar 195,751 ton ke tahun 2019 sebesar 239,407 ton (BPS, 2019). Jumlah tanaman jambu biji menghasilkan di Sulawesi Utara sebanyak 7.476 pohon, rata-rata produksi buah jambi biji $3.315 \mathrm{~kg} /$ tahun. Sedangkan untuk jumlah tanaman jambu biji menghasilkan di Kabupaten Minahasa Utara sebanyak 508 pohon dengan produksi rata-rata $235 \mathrm{~kg} /$ tahun (BPS Sulut, 2020).

Tanaman jambu biji kristal dapat tumbuh dengan baik didaerah dengan intensitas curah hujan antara 2.000-3.000 mm/tahun dengan sebaran hampir merata sepanjang tahun. Jambu kristal dapat berkembang dan berbuah optimal pada suhu sekitar 200-300C disiang hari, kekurangan cahaya matahari menyebabkan penurunan hasil dengan kelembaban udara 3050\% (Kurniawan, 2015). Jambu kristal dapat tumbuh optimum di daerah tropis maupun subtropis dengan ketinggian 5-1200 meter dpl, dengan jenis tanah bertekstur gembur dan subur dapat tumbuh pada tanah liat dan sedikit berpasir (Putri, 2019).

Varietas jambu kristal memiliki biji paling sedikit diantara varietas jambu biji lainnya, buahnya berukuran besar dan memiliki daging buah yang bersih dengan tekstur yang renyah seperti buah apel. Jambu kristal memiliki berat buah optimum $500 \mathrm{gr} / \mathrm{buah}$ dan dapat berbuah sepanjang tahun (Kurniawan, 2015). Buah jambu kristal menjadi buah favorit pilihan masyarakat dan mempunyai prospek yang cerah bagi pelaku bisnis khususnya yang bergerak dibidang agroindustri. Jambu kristal ini juga disukai petani karena budidayanya yang mudah dan berbuah sepanjang tahun sehingga pemanenan buahnya dapat diatur oleh petani serta harga jualnya yang lebih tinggi dan rasanya lebih baik dibandingkan dengan jenis jambu lain (Ramdhona dkk, 2019). Menurut Putri (2019), bahwa buah jambu kristal memiliki manfaat yang sangat baik untuk kesehatan. Kandungan gizi buah jambu kristal dalam $100 \mathrm{gr}$ buah masak segar adalah protein 0,9 gr, lemar 0,3 gr, karbohidrat 12,2 gr, Kalsium (Ca) 14 mg, fosfor $28 \mathrm{mg}$, besi $1,1 \mathrm{mg}$, vitamin A $25 \mathrm{SI}$, vitamin B1 0,02 mg, vitamin C $87 \mathrm{mg}$, air $86 \%$ dengan total kalori sebanyak 49 kalori. Biji jambu kering mengandung minyak atsiri $14 \%$, protein $15 \%$, dan tepung $13 \%$. Manfaat buah jambu kristal selain kaya vitamin $\mathrm{C}$ dapat mengobati diare, disentri, demam berdarah (DBD), gusi bengkak, sariawan, menurunkan kolesterol dan bisa mengobati diabetes.

Kandungan vitamin $\mathrm{C}$ pada jambu biji adalah dua kali lebih banyak dari jeruk manis yang hanya $49 \mathrm{mg}$ per $100 \mathrm{gr}$. Vitamin C sebagai antioksidan, sebagian besar terkonsentrasi di kulit dan daging bagian luarnya yang lunak dan tebal pada saat buah menjelang masak. Kandungan serat pada jambu biji berupa pektin yang bermanfaat untuk menurunkan kolesterol, selain itu jambu biji juga mengandung tannin dan likopen yang bermanfaat untuk memperlancar sistem pencernaan dan sirkulasi darah serta menyerang virus, sedangkan likopen merupakan karoteniod yang memiliki aktivitas antioksidan yang bermanfaat untuk memberikan perlindungan pada tubuh dari beberapa jenis kanker (Susiloadi, 2008).

Menurut Saepudin (2018), bahwa manfaat jambu kristal adalah cocok untuk dijadikan minuman (dijus), baik untuk penderita diare dan kesehatan pencernaan karena jambu kristal banyak mengandung serat, mengobati batuk flu, mengobati sariawan karena kandungan vitamin $\mathrm{C}$ pada jambu, menjaga kesehatan kulit dengan kandungan vitamin E, sebagai anti oksidan, menjaga dan meningkatkan imunitas daya tahan tubuh, memberikan energi bagi tubuh, menjaga kesehatan mata dan tulang serta mencegah infeksi dan virus-virus yang berbahaya bagi.

Sejak tahun 2017 budidaya komoditas jambu kristal sudah mulai dikembangkan di Desa Warisa Kecamatan Talawaan Kabupaten Minahasa Utara. Permintaan produk jambu kristal terus meningkat dari tahun ke tahun, dimana dua tahun terakhir ini permintaan pasar atas produk jambu kristal mencapai 800-1000 kg per minggu. Petani jambu kristal di Desa Warisa hanya mampu memenuhi produksi sekitar 400-500 kg per minggu untuk dipasok di minimarket dengan harga jual mulai Rp. 5.000 s/d 20.000/kg buah jambu. Kekurangan permintaan pasar atas produk jambu kristal ini dapat dijadikan peluang usaha untuk terus dikembangkan. Usahatani budidaya jambu 
biji khususnya jambu biji kristal di Sulawesi Utara masih dapat dikembangkan dengan melihat potensi lahan dan peluang pasar yang tersedia. Langkah strategis mengatasi masalah tersebut, menjadi alasan penulis untuk melakukan penelitian yaitu untuk mengetahui potensi pengembangan budidaya jambu kristal dan peluang pasar yang masih terbuka luas sehingga usahatani ini layak untuk dijalankan oleh petani.

Menurut Pratiwi (2016), bahwa penurunan produksi pada tanaman jambu kristal merupakan variabel yang sangat sensitif yang dapat mempengaruhi jalannya usahatani jambu kristal. Resiko tertinggi penurunan produksi buah jambu kristal antara lain berkaitan dengan kondisi cuaca yang tidak menentu sering berubah, serangan hama dan penyakit tanaman, kurangnya sarana panen dan penanganan pascapanen, kurangnya sarana pengairan, kurangnya sistem keamanan, kesalahan dalam proses pembungkusan buah, kesalahan proses pemangkasan dan belum adanya SOP yang terdokumentasi. Jambu kristal yang berkualitas baik dapat dilihat dari nilai nutrisi, pengujian rasa dan tekstur buah. Tampilan buah merupakan penilaian utama yang pertama kali dilihat oleh konsumen. Oleh karena itu, tampilan buah, khususnya kemulusan buah, seringkali menjadi kendala dalam pemasaran buah baik dari petani di lahan kebun maupun pada tingkat distributor di pasar (Parameswara, 2018).

Pemanenan buah jambu kristal untuk dikonsumsi segar sebaiknya buah dipanen pada umur 109-114 hari setelah bunga mekar. Sedangkan untuk buah yang akan diolah lanjutan sebaiknya buah yang dipanen antara 112-113 hari setelah bunga mekar. Cara panen dengan melihat buah yang sudah matang dan dipetik atau memotong dengan tangkai buah. Ciri-ciri yang menandai bahwa buah sudah bisa dipanen dilihat berdasarkan perubahan warna pada buah yaitu warna kulit buah hijau muda atau kuning kehijauan dan kulit buah mengkilat, aroma buah mulai harum, rasa buah sudah mulai manis dan tekstur daging buah agak lunak (Putri, 2019). Pada saat panen dapat sekaligus dilakukan pemangkasan untuk tanaman dapat kembali bertunas dengan baik dan dapat berbuah dengan cepat.
Permasalahan yang dihadapi oleh petani di Desa Warisa adalah masih kurangnya produksi jambu kristal dengan permintaan pasar yang cukup banyak. Untuk pengembangan usaha perlu dilakukan analisis kelayakan usahatani pada kegiatan budidaya jambu kristal secara finansial dengan menggunakan analisis biaya dan manfaat. Analisis ini dilakukan untuk mengetahui manfaat yang dirasakan petani dan masyarakat sekitar dengan adanya kegiatan usahatani tersebut.

\section{Rumusan Masalah}

Perumusan masalah dalam penelitian ini adalah mengetahui potensi dan peluang pengembangan budidaya jambu kristal dan menganalisis kelayakan finansial usahatani jambu kristal.

\section{Tujuan Penelitian}

Penelitian ini bertujuan untuk mengetahui bagaimana potensi dan peluang pengembangan usahatani jambu biji kristal dan untuk menganalisis kelayakan finansial usahatani jambu biji kristal di Desa Warisa Kecamatan Talawaan Kabupaten Minahasa Utara.

\section{Manfaat Penelitian}

Penelitian ini diharapkan dapat memberikan manfaat ekonomi bagi petani dan masyarakat sekitar dengan usahatani jambu kristal serta informasi tambahan untuk petani yang dapat digunakan sebagai dasar dalam menentukan usaha untuk pengembangan usahatani di Desa Warisa.

\section{METODE PENELITIAN}

\section{Waktu dan Lokasi Penelitian}

Penelitian dilaksanakan pada bulan Juli sampai dengan Oktober 2020. Berlokasi di Desa Warisa Kecamatan Talawaan Kabupaten Minahasa Utara pada usahatani jambu biji kristal.

\section{Jenis dan Sumber Data}

Metode pengumpulan data dalam penelitian ini menggunakan data primer dan sekunder. Data primer diperoleh dengan wawancara langsung kepada petani jambu kristal, Hukum Tua, perangkat desa dan masyarakat di Desa Warisa menggunakan kuesioner yang telah disiapkan. Data sekunder diperoleh dari beberapa instansi BPS, Dinas Pertanian Kabupaten Minahasa Utara, jurnal penelitian dan berbagai sumber lainnya yang mendukung. 


\section{Metode Pengumpulan Sampel}

Metode pengumpulan sampel dalam penelitian ini menggunakan metode Purposive sampling dengan kriteria bahwa petani responden merupakan petani jambu kristal pertama yang telah mengembangkan budidaya jambu kristal secara komersial di Desa Warisa berjumlah satu orang.

\section{Konsep Pengukuran Variabel}

Variabel operasional yang digunakan dalam penelitian ini adalah

(i) Umur usahatani jambu kristal berdasarkan umur ekonomis adalah 10 tahun, dimana produksi dari tanaman jambu kristal dengan usia produktif 10-15 tahun, lalu setelah 15 tahun sudah mulai mengalami penurunan produksi hingga penggantian bibit setelah umur 15 tahun. Modal usaha yang digunakan petani semuanya dari modal sendiri.

(ii) Analisis finansial perhitungannya dilakukan pada luas lahan \pm 5000 M2 dengan jumlah tanaman jambu kristal sebanyak 150 pohon menggunakan jarak tanam 4 x 4 meter.

(iii) Pemanenan buah jambu kristal mulai diperhitungkan dari musim awal menghasilkan yaitu di tahun pertama dihitung dalam satuan kilogram.

(iv) Perincian harga, jumlah dan seluruh input peralatan, biaya tenaga kerja dan biayabiaya lainnya pada penelitian ini datanya berasal dari survey wawancara ke petani dilokasi peneltian dan standar harga disesuaikan dengan harga didaerah tersebut dan diasumsikan sama selama umur usaha.

(v) Perhitungan upah biaya tenaga kerja dalam keluarga disumsikan sama dengan upah untuk tenaga kerja luar keluarga.

(vi) Perolehan hasil panen dalam satu kali panen dianggap terjual semua. Panen di tahun pertama baru satu kali dilakukan, di tahun ke dua panen dua kali dan untuk tahun ke tiga dan seterusnya dilakukan petani sebanyak tiga kali per tahun.

(vii) Tingkat DF yang digunakan dalam perhitungan cashflow adalah tingkat suku bunga kredit usaha mikro bank BRI sebesar $17 \%$ dan diasumsikan tetap selama umur usaha.

\section{Metode Analisis Data}

Analisis data dalam penelitian ini menggunakan analisis deskriptif kuantitatif. Tahapan analisis data dalam penelitian ini yang pertama meli[puti analisis potensi sumberdaya alam dengan pengambilan data profil desa. Tahapan kedua dengan menganalisis kelayakan finansial usahatani jambu kristal yaitu dengan wawancara langsung ke petani jambu kristal. Analisis kelayakan finansial yaitu menganalisis kelayakan biaya dan manfaat dengan menggunakan kriteria investasi NPV, IRR, Net B/C, Payback Period (PP) dan Break Even Point (BEP). Periode usahatani yang dihitung yaitu 10 tahun, berdasarkan umur ekonomis minimal dari pohon jambu kristal dengan perawatan intensif. Harga dan jumlah seluruh input dan output yang digunakan dalam analisis data diasumsikan konstan dari yang berlaku pada tahun 2017 hingga akhir umur usaha. Hasil analisis kelayakan finansial usahatani jambu kristal dapat diketahui potensi dan peluang pasar untuk pengembangan usahatani jambu kristal di Desa Warisa Kecamatan Talawaan Kabupaten Minahasa Utara.

\section{HASIL DAN PEMBAHASAN}

\section{Deskripsi Lokasi Penelitian}

Desa Warisa termasuk dalam wilayah pemerintahan Kecamatan Talawaan Kabupaten Minahasa Utara Provinsi Sulawesi Utara. Jarak Kecamatan Talawaan dari Ibukota Kabupaten Minahasa Utara adalah 17,2 km dan jarak dari Ibukota Provinsi Sulawesi Utara adalah $24,9 \mathrm{~km}$ (BPS, 2019). Jumlah penduduk berdasarkan data profil desa tahun 2019 berjumlah 793 jiwa yang terdiri atas 403 jiwa laki-laki dan 390 jiwa perempuan, dengan jumlah keluarga sebanyak 255 kepala keluarga (KK).

Topografi wilayah ini berbukit dan dataran pada ketinggian sekitar 1-5000 meter dari permukaan laut. Desa Warisa merupakan daerah beriklim hujan hutan tropis sehingga mempengaruhi struktur tanah, jenis tumbuhan dan pola tanam. Desa Warisa memiliki struktur tanah gembur dan sebagian berjenis tanah liat. Rata-rata curah hujan adalah $1,993 \mathrm{~mm}$ per tahun 
dengan suhu rata-rata $26,90-33,720 \mathrm{C}$ dan ratarata kelembaban $78-91 \%$. Hal ini sesuai dengan persyaratan tumbuh untuk tanaman jambu kristal menurut Wang (2011), yaitu pada iklim tropis tanaman jambu kristal dapat bertumbuh dengan baik dengan curah hujan untuk penanaman jambu kristal sekitar 1,000 hingga 3,000 mm per tahun. Pada kelembaban udara 70\% sampai 90\% pada suhu antara 150 hingga $340 \mathrm{C}$ pada kondisi kelembaban ini sangat cocok untuk pertumbuhan jambu kristal. Tanaman jambu kristal dapat tumbuh baik pada ketinggian tempat 50 sampai 1000 mdpl sedangkan penanaman pada ketinggian tempat diatas $1000 \mathrm{mdpl}$ tidak disarankan. Pada kondisi seperti ini dapat menyebabkan lambatnya pertumbuhan dan perkembangan tanaman, bunga dan buah banyak yang tidak berkembang sehingga produksi buah berkurang. Batas wilayah administratif Desa Warisa adalah

- Sebelah utara dengan Desa Lansa,

- Sebelah selatan dengan Desa Patokaan,

- Sebelah timur dengan Desa Teep dan

- Sebelah barat dengan Desa Kampung Baru.

Persyaratan tumbuh untuk tanaman jambu kristal menurut Kurniawan (2015), bahwa jambu kristal dapat tumbuh baik pada ketinggian 5-1.000 mdpl, suhu sekitar 200-300C pada siang hari dengan curah hujan 2.000-3.000 mm per tahun. Tanaman jambu kristal dapat tumbuh baik pada jenis lahan yang gembur dan subur dengan derajat keasaman $(\mathrm{pH})$ tanah sekitar 6-6.5 dengan pengairan yang baik.

Luas wilayah keseluruhan Desa Warisa adalah 8,30 Km2 (Kecamatan Talawaan dalam angka, 2019). Pemanfaatan lahan pertanian di Desa Warisa adalah pekarangan 27 ha, ladang 147 ha, perkebunan kelapa 315 ha, kebun buah-buahan 17 ha, hutan Negara 211 ha dan yang belum dimanfaatkan seluas 148.0 ha.

\section{Tingkat Pendidikan Penduduk}

Tingkat pendidikan penduduk menentukan kualitas sumberdaya manusia di Desa Warisa. Berdasarkan tingka pendidikan jumlah penduduk Desa Warisa adalah sebanyak 793 orang. Jumlah penduduk ini terbagi dalam tingkat pendidikan mulai dari tidak sekolah sampai perguruan tinggi. Tingkat pendidikan penduduk Desa Warisa dapat dilihat pada Tabel 1.

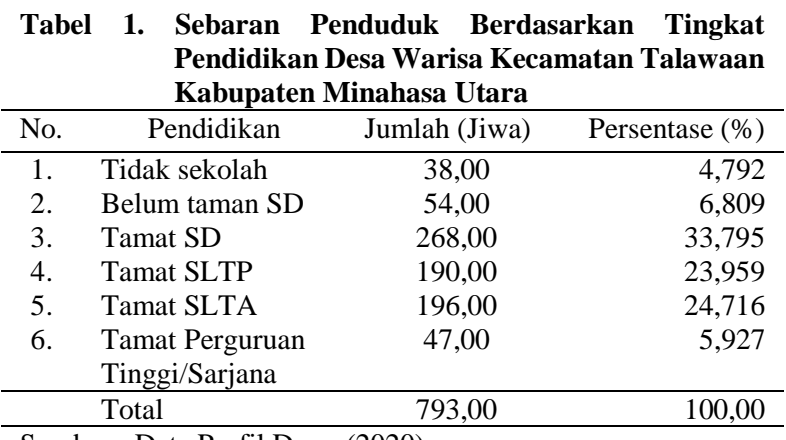

Sumber : Data Profil Desa, (2020)

Tabel 1 menunjukkan bahwa sebaran tingkat pendidikan tertinggi pada penduduk yang taman SD sebanyak 268 jiwa (33,795\%), sedangkan yang terendah adalah penduduk tidak sekolah sebanyak 38 jiwa (4,792\%). Masih rendahnya tingkat pendidikan di Desa Warisa disebabkan oleh faktor kurangnya motivasi dalam diri seseorang dan faktor ekonomi keluarga yang masih rendah. Menurut Soekartawi (2008) bahwa petani dengan tingkat pendidikan relatif tinggi lebih cepat mengadopsi inovasi teknologi dan mempraktekan pertanian yang lebih modern dibandingkan dengan tingkat pendidikan rendah agak sulit untuk menerapkan adopsi inovasi dengan cepat.

Potensi yang menjadi unggulan di Desa Warisa adalah bidang Pertanian, karena sebagian besar penduduknya berada pada sektor pertanian yaitu tanaman pangan (padi ladang dan jagung) dan hortikultura (sayuran dan kacang-kacangan). Di bidang perkebunan petani menanam kelapa dan buah-buahan seperti pisang, rambutan, lansa, duku, dan jambu kristal. Selain di bidang pertanian dan perkebunan masyarakat Desa Warisa juga beternak ayam, itik, sapi, babi dan lain-lain. Jenis pekerjaan yang tertinggi adalah sebagai petani sehingga sangat menunjang program pembangunan pemerintah di sektor pertanian. Sektor pertanian di daerah ini merupakan sektor primer dalam menunjang pembangunan sumberdaya manusia.

Petani responden merupakan faktor yang dapat menentukan keberhasilan usahatani jambu kristal. Petani responden dalam penelitian ini adalah Bapak Wahid Saryanto, umur 43 tahun, menempuh pendidikan Diploma 3 bidang pertanian di Boyolali. Jumlah tanggungan keluarga 3 orang, pengalaman bertani sudah 4 tahun dengan sumber modal sendiri. Petani berusahatani jambu kristal sejak tahun 2017 dengan luas lahan yang ditanami jambu kristal 
\pm 5000 M2 sebanyak 150 pohon. Berdasarkan data bahwa responden diketegorikan dalam umur produktif. Seorang petani dapat meningkatkan usahatani yang dimilikinya dapat dipengaruhi oleh umur. Hal ini sesuai dengan pendapat Soekartawi (2008) dan Prabayanti (2010) bahwa petani berusia lebih muda dan produktif biasanya mempunyai semangat untuk ingin mengetahui tentang berbagai hal baru yang belum merekan diketahui, sehingga dengan demikian mereka cenderung bisa menerima dan menerapkan inovasi teknologi terbaru dibandingkan pada umur non-produktif yang cenderung sangat konservatif dalam menyikapi perubahan inovasi teknologi.

\section{Analisis Kelayakan Finansial Jambu Kristal di Desa Warisa}

\section{Aspek Pasar}

Analisis aspek pasar dilakukan untuk melihat potensi dan peluang pasar yang tersedia karena berkaitan dengan permintaan dan penawaran serta penyerapan pasar terhadap produk yang dihasilkan. Pemaparan tentang aspek pasar maka potensi dan peluang pasar yang berkaitan dengan permintaan dan penawaran, perkembangan harga dan saluran pemasaran yang terjadi pada komoditas jambu kristal dapat diketahui (Sabrina, 2014).

\section{a. Potensi dan Peluang}

Kegiatan budidaya jambu kristal di Kabupaten Minahasa Utara baru dilakukan guna inovasi baru dalam pertanian untuk menunjang ekonomi dan mensejahterakan petani buah jambu kristal. Harga jambu kristal oleh petani dijual mulai Rp. $5.000-20.000$ per kilogram buah yang diserap oleh pasar modern dan dijual seharga Rp. 25.000 - 30.000 per kilogram buah. Permintaan pasar yang tinggi oleh petani jambu kristal di Desa Warisa belum mampu mencukupi karena keterbatasan produksi buah jambu kristal yang dihasilkan. Hal ini menjadi peluang pengembangan usaha budidaya jambu kristal masih terbuka luas bagi petani yang berminat membudidayakan tanaman buah ini.

b. Pemasaran

Petani jambu kristal di Desa Warisa menjual jambu kristal sesuai grade A dan grade $\mathrm{B}$ langsung ke pasar modern dan buah grade $\mathrm{C}$ langsung ke konsumen yang datang ke rumahnya atau kebunnya. Hasil panen buah jambu kristal dijual ke supermarket seperti Hypermart, Freshmart, Indogrosir dan Multimart dan ada juga langsung dijual sendiri ke konsumen. Berdasarkan analisis aspek pasar bahwa usahatani jambu kristal di Desa Warisa layak dilaksanakan dan menghasilkan produk buah jambu kristal yang dapat diterima oleh konsumen.

2. Aspek Finansial

Salah satu kriteria investasi adalah aspek finansial, dengan kriteria ini kegiatan usahatani jambu kristal dapat diketahui sejauh mana memberikan manfaat dan menguntungkan bagi petani, masyarakat dan berbagai pihak terkait. Analisis kelayakan usaha ini dilakukan untuk mengetahui manfaat dan biaya-biaya yang digunakan pada usahatani jambu kristal di Desa Warisa. Petani dapat menggunakan hasil perhitungan kriteria investasi finansial ini sebagai bahan pertimbangan dalam pengambilan keputusan, apakah modal usaha yang ditanam lebih baik pada usaahatani jambu kristal atau di investasi ke lembaga keunagan seperti bank dan lainnya.

\section{a. Manfaat}

Penerimaan hasil yang diterima petani pada kegiatan usahatani jambu kristal di Desa Warisa berasal dari penjualan buah jambu kristal mulai dari tahun pertama hingga di akhir umur usaha. Rata-rata hasil penjualan buah jambu kristal yang diperoleh per tahun yaitu Rp. 107.018.000 pada harga jual buah yaitu Rp. 5000 s/d 20.000 per kilogram dengan jumlah rata-rata produksi buah jambu kristal yang didapat yaitu sebanyak $21.403 \mathrm{~kg}$. Perhitungan produksi dan penerimaan usahatani jambu kristal Desa Warisa dapat dilihat pada Tabel 2.

Tabel 2. Produksi dan Penerimaan Jambu Kristal di Desa Warisa per tahun

\begin{tabular}{cccr}
\hline Tahun & Produksi $(\mathrm{Kg})$ & $\begin{array}{c}\text { Harga } \\
(\mathrm{Rp} / \mathrm{Kg})\end{array}$ & \multicolumn{1}{c}{$\begin{array}{c}\text { Total } \\
\text { Penerimaan }(\mathrm{Rp})\end{array}$} \\
\hline 1 & 256 & 5.000 & 1.280 .000 \\
2 & 2.700 & 5.000 & $13,500,000$ \\
3 & 8.580 & 5.000 & $42,900,000$ \\
4 & 18.000 & 5.000 & $90,000,000$ \\
5 & 27.000 & 5.000 & $135,000,000$ \\
6 & 31.500 & 5.000 & 157.500 .000 \\
7 & 31.500 & 5.000 & 157.500 .000 \\
8 & 31.500 & 5.000 & 157.500 .000 \\
9 & 31.500 & 5.000 & 157.500 .000 \\
10 & 31.500 & 5.000 & 157.500 .000 \\
\hline Jumlah & 214.036 & & 1.070 .180 .000 \\
\hline Rata-rata & $21.403,6$ & \\
\hline Sumber : Data primer diolah, 2020 &
\end{tabular}


Tabel 2 menunjukkan bahawa total produksi dan total penerimaan terendah terdapat pada tahun pertama sebesar $\mathrm{Rp}$. 1,280,000.00 dikarenakan pada tahun pertama usaha jambu kristal baru mulai berproduksi dari awal tanam dan penerimaan tertinggi pada tahun keenam yaitu Rp. 157,500,000.00. Keuntungan usaha jambu kristal di Desa Warisa dapat dilihat pada Tabel 3.

Tabel 3. Keuntungan Usahatani Jambu Kristal di Desa Warisa per tahun

\begin{tabular}{cccr}
\hline Tahun & \multicolumn{1}{c}{$\begin{array}{c}\text { Total } \\
\text { Penerimaan }(\mathrm{Rp})\end{array}$} & $\begin{array}{c}\text { Total } \\
\text { Biaya }(\mathrm{Rp})\end{array}$ & $\begin{array}{c}\text { Keuntungan } \\
(\mathrm{Rp})\end{array}$ \\
\hline 1 & 1.280 .000 & $78,116,000$ & -76.836 .000 \\
2 & $13,500,000$ & $30,201,417$ & -16.701 .417 \\
3 & $42,900,000$ & $39,676,417$ & 3.223 .583 \\
4 & $90,000,000$ & $24,868,084$ & $65,131,916$ \\
5 & $135,000,000$ & $24,868,084$ & $110,131,916$ \\
6 & 157.500 .000 & $24,868,084$ & $132,631,916$ \\
7 & 157.500 .000 & $24,868,084$ & $132,631,916$ \\
8 & 157.500 .000 & $24,868,084$ & $132,631,916$ \\
9 & 157.500 .000 & $24,868,084$ & $132,631,916$ \\
10 & 157.500 .000 & $24,868,084$ & $132,631,916$ \\
\hline Jumlah & 1.070 .180 .000 & $322,070,422$ & 748.109 .578 \\
\hline Rata-rata & 107.018 .000 & $32.207 .042,2$ & 74.810 .957 \\
\hline Sumber
\end{tabular}

Sumber : Data primer diolah (2020)

Tabel 3 menunjukkan bahwa keuntungan yang diperoleh dari usahatani jambu kristal di Desa Warisa selama periode usaha 10 tahun dilaksanakan sebesar Rp. 748,109,578.00 dan keuntungan rata-rata diperoleh sebesar $\mathrm{Rp}$. $74,810,957.00$ per tahun.

b. Nilai Sisa

Nilai sisa merupakan tambahan manfaat yang diperoleh petani dalam usaha budidaya jambu kristal diakhir tahun dari barang modal yang tidak habis pakai selama umur usaha. Nilai sisa yang diperoleh petani sebesar Rp. 2,522,356.00.

c. Biaya usahatani

Biaya-biaya yang digunakan untuk kegiatan usahatani adalah untuk memenuhi sarana produksi dan prasarana lainnya yang dibutuhkan untuk menunjang jalannya usaha budidaya jambu kristal adalah sebagai berikut:

1. Lahan

Lahan yang digunakan petani untuk usahatani budidaya jambu kristal adalah milik sendiri, pada saat dibeli seharga Rp. 40,000,000.00.
2. Bibit

Pembelian bibit tanaman jambu kristal oleh petani dipesan dari bogor dengan harga per bibit Rp. 50,000.00. Jumlah bibit yang ditanam sebanyak 150 bibit dengan biaya yang dikeluarkan pada saat pembelian sebesar Rp. 7,500,000.00 dimana bibit tanaman jambu yang dibeli merupakan bibit yang sudah siap ditanam.

3. Pupuk

Jenis pupuk yang digunakan petani untuk kegiatam usahatani jambu kristal di Desa Warisa pada umumnya adalah pupuk kandang diberikan sekali setahun, pupuk NPK, SP-36 dan $\mathrm{KCl}$ diberikan 3 kali setahun. Ratarata jumlah pupuk yang digunakan oleh petani jambu kristal per tahun adalah pupuk kandang $1000 \mathrm{~kg}$, pupuk NPK $450 \mathrm{~kg}$, pupuk SP-36 600 $\mathrm{kg}$, pupuk KCL $300 \mathrm{~kg}$ dan pupuk cair Nasa 4 liter. Total pengeluaran petani dalam penggunaan pupuk dalam satu tahun adalah sebanyak Rp. 10,800,000.00.

4. Obat-obatan

Obat-obatan yang digunakanoleh petani jambu kristal Desa Warisa adalah ceratis, topzone, gandasil, isadora dan petrogenol atraktan. Harga obat-obatan menggunakan harga obat setempat karena didapatkan dari toko pertanian diwilayah petani. Jumlah penggunaan masing-masing obat dalam satu tahun disesuaikan dengan kondisi atau jenis serangan OPT yang terjadi. Total pengeluaran untuk obat-obatan pengendalian OPT dalam satu tahun adalah Rp. 1,500,000.00.

5. Peralatan

Harga-harga peralatan yang digunakan merupakan harga berlaku atau harga yang langsung dibayarkan oleh petani pada saat membelinya. Total pengeluaran untuk peralatan per tahun adalah untuk tahun pertama sebesar Rp. 8,91,000,00 tahun kedua sebesar Rp. $8,000,000,00$ dan tahun ketiga sebesar Rp. $16,000,000,00$.

6. Tenaga Kerja

Petani jambu kristal Desa Warisa umumnya menggunakan tenaga kerja luar keluarga dan menggunakan jasa tenaga kerja hanya pada waktu tertentu dan diperlukan saja karena sangat tidak mudah untuk mencari tenaga kerja dilokasi kebun. Pada tahun pertama terdapat pengeluaran biaya tenaga kerja sebesar Rp. 7,300,000.00 yang digunakan 
untuk persiapan tanam, penanaman jambu kristal. Pada tahun kedua biaya tenaga kerja yaitu sebesar Rp. 5,500,000,00 dan tahun ketiga sebesar Rp. 6,450,000.00 hal ini dikarenakan penambahan tenaga kerja pada saat pembungkusan buah dimana buah sudah banyak yang dibungkus. Tanaman jambu kristal sudah mulai menghasilkan buah, penggunaan tenaga kerja dapat dikurangi disesuaikan kondisi pada saat panen, jika hasil panen banyak maka tenaga kerja ditambah sedangkan jika hasil panen sedikit maka tenaga kerja akan dikurangi. Tenaga kerja pria jumlah upah yang diberikan sebesar Rp. 100,000.00/hari untuk pekerjaan persiapan tanam, penanaman, penyiraman, penyiangan, penyemprotan, pemupukan dan pemanenan. Pembungkusan calon buah jambu kristal dikerjakan oleh tenaga kerja wanita yang diberikan upah Rp. 250/buah yang dibungkus, semakin banyak buah yang dibungkus maka semakin besar upah yang diterima. Tenaga kerja yang digunakan dalam budidaya jambu kristal berasal dari sumberdaya manusia di Desa Warisa.

7. Kelayakan usahatani jambu kristal

Analisis kelayakan investasi kegiatan usahatani jambu kristal Desa Warisa dapat menggunakan kriteria investasi yaitu Net Present Value (NPV), Net Benefit Cost Ratio (Net B/C), Internal Rate of Return (IRR), Payback Period (PP) dan Break Even Point (BEP). Perhitungan dari masing-masing kriteria investasi cashflow kegiatan usahatani jambu kristal Desa Warisa dapat dilihat pada Tabel 4.

Tabel 4. Perhitungan Kelayakan Finansial Usahatani Jambu

\begin{tabular}{lclc}
\multicolumn{4}{c}{ Kristal Desa Warisa } \\
Kriteria Investasi & Nilai & $\begin{array}{c}\text { Indikator } \\
\text { Kelayakan }\end{array}$ & $\begin{array}{c}\text { Hasil } \\
\text { Kelayakan }\end{array}$ \\
\hline NPV (Rp) & 202.669 .253 & $>0$ & Layak \\
IRR (\%) & 29,76 & $>17$ & Layak \\
Net B/C & 3,6 & $>1$ & Layak \\
PP (tahun) & 3 tahun 6 bulan & $<10$ tahun & Layak \\
BEP produksi (Kg) & 66,414 & $>214.036$ & Layak \\
BEP harga (Rp) & 1,504 & $>5,000$ & Layak \\
\hline Sumber : Data primer diolah (2020) & &
\end{tabular}

\section{Net Present Value (NPV)}

NPV dihitung untuk mengetahui manfaat bersih yang diperoleh selama periode kegiatan usahatani dengan hasil perhitungan NPV $>0$ maka usaha layak untuk dilaksanakan, jika NPV $<0$ usaha tidak layak dilaksanakan dan jika NPV $=0$ maka usaha dalam kondisi BEP dimana usaha tidak untung dan tidak rugi (Ibrahim (2009). Dari hasil perhitungan yang diperolah nilai NPV pada kegiatan usahatani jambu kristal adalah sebesar Rp. 202,669,253.00. Nilai NPV ini menunjukkan bahwa kegiatan usahatani jambu kristal Desa Warisa layak untuk dilaksanakan, karena menghasilkan manfaat bersih sebesar Rp. 202,669,253.00. Nilai NPV yang diperoleh dari hasil perhitungan ini lebih besar dari nol (NPV > $0)$.

\section{Internal Rate of Return (IRR)}

Perhitungan kelayakan usahatani budidaya jambu kristal pada tingkat IRR yaitu dengan membandingkan nilai Social Opportunity Cost of Capital (SOCC) dengan tingkat IRR, apabila hasil IRR lebih besar dari SOCC maka usaha layak untuk dilaksanakan, jika nilai IRR sama dengan SOCC artinya usaha dalam kondisi BEP dan jika nilai IRR dibawah SOCC artinya usaha tidak layak dilaksanakan (Ibrahim (2009). Nilai SOCC yang digunakan sebagai pembanding dan indikator kelayakan berdasarkan IRR adalah sebesar $17 \%$. Nilai SOCC merupakan nilai suku bunga pinjaman kredit usaha mikro bank BRI yaitu bank terdekat di Desa lokasi penelitian. Berdasarkan hasil perhitungan diperoleh nilai IRR dari kegiatan usaha budidaya jambu kristal Desa Warisa adalah sebesar 29,76\%. Artinya petani mampu mengembalikan sampai bunga pinjaman bank sebesar $29,76 \%$. Nilai yang diperoleh ini masih lebih besar dibandingkan dengan suku bunga bank yang berlaku sekarang yaitu 17\%, sehingga dapat disimpulkan bahwa kegiatan usahatani jambu kristal di Desa Warisa layak untuk dilaksanakan.

\section{Net Benefit Cost Ratio (Net B/C)}

Nilai Net B/C yang diperoleh dari kegiatan usahatani jambu kristal di Desa Warisa sebesar 3,6 artinya dari setiap tambahan biaya sebesar Rp, 1,00 akan menghasilkan manfaat tambahan bagi petani sebesar 3,6. Suatu usaha layak dilaksanakan apabila Net $\mathrm{B} / \mathrm{C}>1$ dan tidak layak dilaksanaka apabila Net B/C < 1 (Gittinger (2008), Husnan (2008), sehingga dapat disimpulkan bahwa kegiatan usahatani jambu kristal di Desa Warisa layak dilaksanakan.

\section{Payback Period (PP)}

Payback periode (PP) digunakan untuk menghitung jangka waktu pengembalian modal dari kegiatan budidaya yang dilaksanakan. Payback period dalam kegiatan usahatani jambu kristal di Desa Warisa didapatkan 3 tahun 6 bulan. Payback period (PP) digunakan untuk menghitung jangka waktu pengembalian modal usaha dari 
kegiatan budidaya yang dilaksanakan. Payback period dalam kegiatan usahatani jambu kristal di Desa Warisa didapatkan 3 tahun 6 tahun. Payback period bila dibandingkan dengan umur usahatani budidaya jambu kristal selama 10 tahun maka jangka waktu pengembalian modal kegiatan usahatani budidaya jambu kristal lebih cepat dari umur usaha sehingga usahatani jambu kristal ini layak untuk dilaksanakan.

\section{Break Even Point (BEP)}

Perhitungan BEP usahatani jambu kristal Desa Warisa menunjukkan bahwa titik impas produksi diperoleh sebesar $66,414 \mathrm{~kg}$ artinya pada kondisi ini produksi yang dihasilkan petani tidak untung dan tidak rugi, produksi diatas nilai tersebut petani mengalami keuntungan. Sedangkan titik impas harga jambu kristal diperoleh sebesar Rp. 1,504 per kg, artinya pada kondisi harga ini petani tidak untung dan tidak rugi, harga diatas nilai tersebut menguntukngkan petani. Usahatani jambu kristal Desa Warisa adalah layak untuk dilaksanakan, dimana BEP produksi < jumlah produksi yaitu sebesar 66,414 kg kurang dari 214,036 kg dan BEP harga < harga jual produksi yaitu Rp. 1,504,00 lebih kecil dari Rp. $5,000,00$. Usahatani jambu kristal Desa Warisa menguntungkan dan layak untuk dilaksanakan karena penghasilan dari produksi dan harganya melebihi nilai titik impas (BEP). Kondisi ini sejalan dengan pendapat dari Soekartawi (2006) yang menjelaskan bahwa jika BEP produksi kurang dari jumlah produksi dan jika BEP harga kurang dari harga jual, maka usahatani berada pada posisi menguntungkan.

\section{KESIMPULAN DAN SARAN}

\section{Kesimpulan}

Berdasarkan hasil penelitian analisis kelayakan finansial usahatani jambu biji kristal (Psidium guajava L.) (studi kasusu petani jambu biji kristal di Desa Warisa Kacamatan Talawaan Kabupaten Minahasa Utara) dapat ditarik kesimpulan sebagai berikut :

1. Usahatani jambu kristal di Desa Warisa layak untuk dilaksanakan dengan melihat potensi sumberdaya alam dan sumberdaya manusia yang tersedia termasuk potensi dan peluang pasar masih terbuka luas dan usahatani yang menguntungkan bagi petani.
2. Perhitungan analisis finansial kegiatan usahatani jambu kristal Desa Warisa layak untuk dilaksanakan karena memenuhi semua kriteria investasi kelayakan yaitu Net Present Value (NPV) 202,699,253 > 0 pada DF 17\%, Net Benefit Cost Ratio (Net B/C) 3,6>1, Internal Rate of Return (IRR) 29,76\% > 17\%, Payback Period (PP) 3 tahun 6 bulan dan Break Even Point (BEP) terjadi pada saat jambu kristal menghasilkan 66,414 kg dengan harga Rp. 1.504. Hasil perhitungan ini menunjukkan bahwa usahatani jambu kristal menguntungkan dan dapat dijadikan pilihan untuk usaha.

\section{Saran}

Beberapa saran yang dapat diberikan pada kegiatan usahatani jambu kristal yaitu :

1. Diperlukan sosialisasi dan pendampingan untuk peningkatan pengetahuan petani melalui program pelatihan dan pembelajaran dari pemerintah setempat yang berkaitan dengan teknik budidaya jambu kristal yang sesuai pedoman GAP (Good Agricultural Practice) agar dapat meningkatkan produksi.

2. Terkait dengan ketersediaan sarana produksi diperlukan koordinasi dengan pihak terkait sehingga diharapkan saat dibutuhkan tidak terjadi kelangkaan sarana input tersebut. Juga untuk mengatasi penurunan jumlah produksi perlu dilakukan pengendalian OPT dengan tepat agar tanaman tidak terserang hama dan penyakit dan hasil produksi dapat stabil.

3. Penelitian selanjutnya diharapkan untuk pengkajian lebih lanjut tentang cara optimalisasi produksi jambu kristal dan bentuk pemasaran jambu kristal.

\section{DAFTAR PUSTAKA}

BPS Minasaha Utara. 2019. Kecamatan Talawaan dalam Angka.

BPS Sulawesi Utara. 2020. Jumlah Menghasilkan, Produksi dan Hasil per Pohon Jambu Biji Menurut Kabupaten / Kota di Provinsi Sulawesi Utara.

Gittinger, J.P. 2008. Analisis Ekonomi Proyekproyek Pertanian. Jakarta (ID): UI Press. (2): 57-69. 
Husnan dan Muhammad. 2008. Studi Kelayakan Proyek. Unit Penerbit dan Percetakan Yogyakarta.

Ibrahim, Y. 2009. Studi Kelayakan Bisnis. Edisi Revisi. Penerbit Rineka Cipta. Anggota IKAPI No. 112/DKI/90. Jakarta.

Kurniawan, D. 2015. Mengenal Jambu Kristall. Direktorat Jenderal Hortikultura. Kementerian Pertanian Indonesia. https://www/google.co.id/hortikultura.pert anian.go.id.

Parameswara, Y.S. 2018. Perbaikan Teknik Pemberongsingan memalui Aplikasi Pestisida untuk Meningkatkan Kemulusan Buah Jambu Kristal (Psidium guajava L.). Skripsi IPB. Bogor.

Prabayanti, H. 2010. Faktor-faktor yang Mempengaruhi Adopsi Biopestisida oleh Petani di Kecamatan Mojogedang Kabupaten Karanganyar. Skripsi. Fakultas Pertanian Sebelas Maret. Surakarta.

Pratiwi, A.I. 2016. Analisis resiko Usahatani Jambu Biji (Psidiun guajava L.) Varietas Kristal. Universitas Padjadjaran. Bandung.

Putri, K.S. 2019. Budidaya Jambu Kristal. Dinas Tanaman Pangan dan Hortikultura. Provinsi Jawa Barat.

Ramdhona, C. Dini Rochdiani dan Budi Setia. 2019. Analisis Kelayakan Usahatani Jambu Kristal (Psidium guajava L.) (Studi Kasus pada Pengembang Budidaya Jambu Kristal di Desa Bangunsari Kecamatan Pamarican Kabupaten Ciamis). Jurnal Ilmiah Mahasiswa Agroinfo Galuh. Volume 6. Nomor 3. September 2019: 596-603.
Sabrina, P.A. 2014. Perbandingan Analisis Kelayakan Usaha Jambu Kristal (Psidium guajava L.) Petani Mandiri dan Petani Binaan ICDF Kabupaten Bogor. Bogor (ID): Pertanian. Institut Pertanian Bogor.

Saepudin, E. 2018. Budidaya Jambu Kristal. https://sikapdaya.kemsos.go.id/uploads/ downloadablefile/pemantapankewirausaha-an-kt-budidaya-jambukristal-eep-saepu dinpdf 5d19c2382d5cl.pdf. diakses tanggal 6 Januari 2020.

Soekartawi. 2006. Analisis Usahatani UI. Press. Jakarta dalam Asnidar dan Asrida. 2017. Analisis Kelayakan Usaha Home Industry Kerupuk Opakdi Desa Paloh Meuasah Dayah Kecamatan Muara Satu Kabupaten Aceh Utara. Jurnal S. Pertanian 1 (1): 39-47. ISSN: 20880111. Fakultas Pertanian Universitas Almuslim. Aceh.

Soekartawi. 2008. Prinsip Dasar Komunikasi Pertanian. Jakarta: UI Press.

Susiloadi A. 2008. Petunjuk Teknis Teknologi Pembibitan Jambu Biji. Balai Penelitian Tanaman Buah Tropika. Puslitbang Hortikultura. Balitbangtan Kementerian Pertanian.

Wang, T.H. 2011. Taiwan Guava Produstion Manual. Horticulture Crop Training and Demonstration Centre. Technical Mission of the Republic of China Taiwan. 